Supplement of Biogeosciences, 14, 2199-2224, 2017

http://www.biogeosciences.net/14/2199/2017/

doi:10.5194/bg-14-2199-2017-supplement

(C) Author(s) 2017. CC Attribution 3.0 License.

(c) (i)

Supplement of

\title{
Reviews and syntheses: Isotopic approaches to quantify root water uptake: a review and comparison of methods
}

Youri Rothfuss and Mathieu Javaux

Correspondence to: Youri Rothfuss (y.rothfuss@fz-juelich.de)

The copyright of individual parts of the supplement might differ from the CC-BY 3.0 licence. 
White et al. (1985)

Ehleringer et al. (1991)

Walker and Richardson (1991)

Walker and Richardson (1991)

Dawson and Ehleringer (1991)

Flanagan et al. (1992)

Busch et al. (1992)

Dawson and Ehleringer (1993)

Thorburn and Walker (1994)

Lin and Sternberg (1994)

Phillips and Ehleringer (1995)

Brunel et al. (1995)

Leroux et al. (1995)

Thorburn and Ehleringer (1995)

Komor and Magner (1996)

Dawson and Pate (1996)

Emerman and Daws

Bleby et al. (1997)
Brunel et al. (1997)

Brunel et al. (1997)

Dodd et al. (1998)

Le Roux and Bariac (1998)

Midwood et al. (1998)

Ewe et al. (1999)

Roupsard et al. (1999)

Cramer et al. (1999)

Meinzer et al. (1999)

Alstad et al. (1999)

Pate and Dawson (1999)

Plamboeck et al. (1999)

Zhang et al. (1999)

Zubrinich et al. (2000)

Moreira et al. (2000)

Stratton et al. (2000)

Williams and Ehleringer (2000)

Williams and Ehleringer (2000)

Grieu et al. (2001)

Retzlaff et al. (2001)

Sekiya and Yano (2002)

Schwinning

Schwinning et al. (2002)

Ewe and Sternberg (2002)

Ewe and Sternberg $(200$

Martin-Gomez et al. (2015)

Martin-Gomez et al.

Angert et al. (2003).
Snyder and Williams (2003)

February et al. (2004)

Zegada-Lizarazu and Iijima (2004)

Chimner and Cooper (2004)

Sekiya and Yano (2004)

Ogle et al. (2004)

Andrade et al. (2005)

Iijima et al. (2005).

Araki and Iijima (2005)

Zegada-Lizarazu and Iijima (2005)

Zegada-Lizarazu and lijima
Geochimica et Cosmochimica Acta

Oecologia

Chemical Geology

Oecologia

Nature

Plant, Cell and Environme

Ecological Applications

Geochimica et Cosmochimica Acta

Oecologia

Bulletin of Marine Science

Trees-Structure and Function

Decologia

lant and Soil

Water Resources Research

Oecologia

Plant and Soil

Plant, Cell and Environmen

Journal of Hydrology

Oecologia

Oecologia

Oecologia

Plant and Soil

Forest Ecology and Management

Functional Ecology

Agricultural Water Management

\section{Decologia}

Oecologia

Agroforestry Systems

Oecologia

Agricultural Water Management

Tree Physiology

Plant and Soil

Oecologia

Ecological Monographs

Ecological Monographs

Plant and Soil

Trees-Structure and Function

Field Crops Research

Oecologia

Plant and Soil

Oecologia

Oecologia

Environmental and Experimental Botany

Oecologia

Functional Ecology

South African Journal of Science

Plant Production Science

Plant and Soil

Field Crops Research

Ecology

Trees-Structure and Function

Plant Production Science

Plant and Soil

Plant Production Science

Comptes Rendus Geoscience and DS-double

ingle isotope

DS

DS

DS

DS isotopic type

abundance

/labeling

study

Trees None

Natural Grasses and shrubs None

Natural Crops and trees None

$\begin{array}{lll}\text { Natural } & \text { Grasses and shrubs } & \text { None } \\ \text { Natural Trees } & \end{array}$

$\begin{array}{lll}\text { Natural } & \text { Trees } & \text { None } \\ \text { Natural } & \text { Shrubs and trees } & \text { None }\end{array}$

Natural Shrubs and trees None

Natural Trees

Natural Trees None

Natural Trees $\quad$ Texture

Natural Trees Structure

Natural Grasses and shrubs Texture

Natural Trees None

Natural Trees Texture

Natural Shrubs and trees Texture

Labeling Crops $\quad$ Artificial soil

Natural Grasses Structure

Natural Shrubs

Natural Trees Classification

Natural Grasses Texture and classification

Natural Grasses and shrubs Formation

Natural Shrubs and trees Texture

Natural Trees None

Natural Trees Texture, structure, and

Natural Trees

Natural Trees

Natural Trees

Natural Trees

Labeling Trees

Natural Grasses

Natural Trees

Labeling Grasses and shrub

Natural Trees

Natural Trees

Labeling Trees

Labeling Grasses

Natural Trees

Natural Crops Texture and chemical properties

Labeling Grasses and shrubs None

Labeling Trees

Natural Trees

Natural Trees

Labeling Trees

Natural Shrubs and trees

Labeling Trees

Natural Grasses

Labeling Crops

Natural Shrubs

Labeling Crops

Natural Shrubs

Natural Trees

Labeling Crops

Labeling Crops

Labeling Crops

Labeling Crops particle size distribution

None

None

None

Classification

Particle size distribution

Classification

Texture and classification

Texture

Classification

Classification

Classification (non FAO)

None

Classification

None

None

Texture

Texture

Texture

None

None

Texture and physical properties 2

Formation

Linear mixing model function of time

None

Direct inference (Brunel et al., 1995)

None

None

Direct inference (Brunel et al., 1995)

None

Direct inference (Brunel et al., 1995)

None

Direct inference (Brunel et al., 1995)

Direct inference (Brunel et al. 1995)

Direct inference (Brunel tol, 1995)

None

None

Direct inference (Brunel et al., 1995)

Direct inference (Brunel et al., 1995)

Direct inference (Brunel et al., 1995)

None

Direct inference (Brunel et al., 1995)

None

None

Direct inference (Brunel et al., 1995)

Direct inference (Brunel et al., 1995)

None

4-end mixing model with three tracers: $\delta^{18} \mathrm{O}$ Natural $+\delta^{2} \mathrm{H}$ labelled $+\delta^{3} \mathrm{H}$

WAVES

Direct inference (Brunel et al., 1995)

Direct inference (Brunel et al., 1995)

None

Direct inference (Brunel et al., 1995)

None

Direct inference (Brunel et al, 1995)

Direct inference (Brunel et al., 1995)

3-end mixing model $\delta^{18} \mathrm{O}$ and $\delta^{2} \mathrm{H}$ are uncorrelated None

Direct inference (Brunel et al., 1995)

None

None

None

Direct inference (Brunel et al., 1995)

Direct inference (Brunel et al., 1995) 
Fritzsche et al. (2006)

Greaver and Sternberg (2006)

Holland et al. (2006)

Zegada-Lizarazu et al. (2006)

Kulmatiski et al. (2006)

Iijima et al. (2007)

McCole and Stern (2007)

Mccole and Stern (2007)

Zegada-Lizarazu et al. (2007)

Asbjornsen et al. (2007)

Asbjornsen et al. (2007)

Li et al. (2007)

Snyder and Williams (2007)

Nippert and Knapp (2007)

Querejeta et al. (2007)

Q

Schwinning (2008)

Asbjornsen et al. (2008)

(Costelloe et al., 2008)

Sánchez-Perez et al. (2008)

Fernandez et al. (2008)

Rowland et al. (2008)

Izumi et al. (2009)

Saha et al. (2009)

Eggemeyer et al. (2009)

Saha et al. (2010)

Armas et al. (2010).

Wang et al. (2010)

Wang et al. (2010)

Liu et al. (2010)

Feikema et al. (2010)

Kulmatiski et al. (2010)

Kowaljow and Fernandez (2011)

Sun et al. (2011)

Xu et al. (2011)

Yang et al. (2011)

Drake et al. (2011)

Liu et al. (2011)

Zhang et al. (2011)

Jia et al (2012)

Moreno-Gutierrez et al. (2012)

Nie et al. (2012)

Bijoor et al. (2012)

Bertrand et al. (2012)

Meissner et al. (2012)

Nie et al. (2012)

Rossatto et al. (2012)

Rothfuss et al. (2012)

Stumpp et al. (2012)

Stumpp et al. (2012)

February et al. (2013)

$\mathrm{Hu}$ et al. (2013)

Kerhoulas et al. (2013)

Singer et al. (2013)

Stahl et al. (2013)

Stahl et al. (2013)
Tree Physiology

Australian Journal of Botany

Plant Production Science

Plant and Soil

Plant Production Science

Journal of Hydrology

Journal of Hydrology

Plant Production Science

Agriculture, Ecosystems and Environment S

Agriculture, Ecosystems and Environment S

Journal of Hydrology

Forest Ecology and Management

Oecologia

apid Communications in

Mass Spectrometry

Oecologia

Plant and Soil

Oecologia

Hydrological Processes

Agroforestry Systems

Transactions of the ASABE

Plant Production Science

Ecohydrology

Tree Physiology

Wetlands Ecology and Management

Oecologia

Agricultural Water Management

Agricultural Water Management

Agricultural and Forest Meteorology

Plant and Soil

New Phytologist
Journal of Arid Environments

Tree Physiology

Ecohydrology

Plant and Soil

Tree Physiology

European Journal of Soil Biology

Journal of Hydrology

PLOS ONE

New Phytologist

Journal of Hydrology

Urban Ecosystem

Ecohydrology

Journal of Hydrology

Environmental and Experimental Botany

Journal of Hydrology

Vadose Zone Journal

Hydrology and Earth System Sciences

Plant Ecology

Forest Ecology and Management

Ecohydrology

Oecologia

Oecologia

Natural Trees
Natural None

Natural Trees

Classification

Texture

Labeling Crops

Natural Grasses

Labeling Crops

Natural Trees

Natural Trees

Natural Crops

Natural Grasses, crops, and trees

Natural Grasses, crops, and trees

Natural Trees

Labeling Trees

Natural Grasses

Natural Trees

Natural Trees

Natural Grasses, shrubs, and tree

Natural Trees

Natural Grasses and trees

Labeling Crops

Labeling Crops

Natural Trees

Natural Trees

Natural Trees

Natural Crops

Natural Crops

Natural Crops

Natural Trees

Labeling Trees

Labeling Shrubs

Natural Trees

Natural Trees

Natural Trees

Natural Trees

Natural Crops

Natural Grasses and shrubs

Natural Trees

Natural Trees

Natural Trees

Natural Shrubs and trees

Natural Shrubs

Natural Grasse

Natural Grasses

Natural Grasse

Natural Shrubs

Natural Grasses and shrubs

Natural Trees

Labeling Trees

Labeling Trees
Physical properties

Classification

Thucture

Texture and classification

Texture and classification

Classification

Texture

Texture

None

Classification

Texture and classification

None

Particle size distribution

and physical properties

None

Texture and classification

None

Classification

Formation

Texture

Texture

Texture

Classification

Texture

Texture

Texture

Classification

None

Particle size distribution

Texture

Texture

Classification

Texture

Urban soils

Classification

Texture and bulk density

Texture

Classification

Particle size distribution

and physical propertie

Texture

Particle size distribution

None

Classification

Classification

Classification

Classification horizon

None

None

Direct inference (Brunel et al., 1995)

None

Direct inference (Brunel et al., 1995)

IsoSource (Phillips and Gregg, 2003)

Direct inference (Brunel et al., 1995) None

IsoSource (Phillips and Gregg, 2003)

IsoSource (Phillips and Gregg, 2003)

None

None

Direct inference (Brunel et al., 1995)

Direct inference (Brunel et al., 1995

Direct inference (Brunel et al., 1995)

None

Direct inference (Brunel et al., 1995)

None

IsoSource (Phillips and Gregg, 2003)

None

Direct inference (Brunel et al. 1995)

Direct inference (Bumelet., 1995)

IsoSource (Phillips and Gregg, 2003)

Thorburn (1993) - 2D mixing model Proportional ${ }^{2} \mathrm{H}$ uptake

None

None

None

None

IsoSource (Phillips and Gregg, 2003)

IsoSource (Phillips and Gregg, 2003)

Direct inference (Brunel et al. 1995)

Direct inference (Brunel et al. 1995)

Direct inference (Brunel et al., 1995)

Thorburn (1993) - 2D mixing, 195)

IsoSource (Phillips and Gege, 2003 )

IsoSource (Phillips and Gregg, 2003)

Iso Souce (Phillips and Gregg, 2003)

IsoSource (Phillips and Gregg, 2003)

SiSPAT-Isotopes

HYDRUS-1D

HYDRUS-1D

Direct inference (Brunel et al., 1995)

Direct inference (Brunel et al., 1995)

Direct inference (Brunel et al., 1995)

Direct inference (Brunel et al. 1995)

Direct inference (Brunel et a1., 1995)

Romero-Saltos et al. (2005) 
Goebel et al. (2015)

Schwendenmann et al. (2015)

Huang and Zhang (2015)

Prechsl et al. (2015)

Dai et al. (2015)

Deng et al. (2015)

Ellsworth and Sternberg (2015)

Gu et al. (2015)

Link et al. (2015)

Yin et al. (2015)

Barbeta et al. (2015)

Voltas Voltas et al. (2015)et al.

Journal of Vegetation Science

Natural Trees

Ecohydrology DS

Agriculture, Ecosystems and Environment S Oecologia

Biogeosciences

Ecohydrology

Journal of Plant Interactions

Journal of Hydrology

Ecological Applications

Forest Systems

PLOS ONE

Ecology

$\begin{array}{ll}\text { Ecology } & \text { DS } \\ \text { Agricultural Water Management } & \text { S }\end{array}$

Oecologia

Ecohydrology

Water

Oecologia

Plant and Soil

Environmental Earth Science

Ecohydrology

Environmental Earth Sciences

Agroforestry Systems

Journal of Hydrology

Global Change Biology

Hydrobiologia

New Phytologist

Agricultural and Forest Meteorology

Scientific Reports

Journal of Arid Land

Journal of Hydrology

Yang et al. (2015)

Warren et al. (2015)

Beyer et al. (2016)

del Castillo et al. (2016)

Priyadarshini et al. (2016)

Gaines et al. (2016)

Zhao et al. (2016)

Chen et al. (2016)

Guo et al. (2016)

Zhu et al. (2016a)

Song et al. (2016)

Song et al. (2016)

Wu et al. (2016a)

Wu et (2016a)

Wu et al. (2016c)

Zhu et al. (2016a)

Evaristo et al. (2016)

Evaristo et al. (2016)
Muench et al. (2016)

Muench et al. (2016)
Volkmann et al. (2016)

Volkmann et al. (2016)

Wu et al. (2016b)

Ma and Song (2016)
Trogisch et al. (2016)

Forest Ecology and Management

Ecohydrology

Tree Physiology

Caten

Environmental Science an

Pollution Research

Journal of Integrative Agriculture

Journal of Arid Land

Environmental and Experimental Botany

Environmental and Experimental Botany

Environmental Earth Sciences

Agricultural Water Management

Journal of Arid Land

PLOS ONE

Hydrological Processes

Plant Ecology

New Phytologis

Journal of Applied Ecology

Science of the Total Environme

Forest Ecology and Management

Natural Grasses and shrubs

Natural Trees

Natural Shrubs

Natural Crops

Natural Trees

Natural Grasses

Natural Trees

Natural Shrubs

Labeling Trees

Natural Shrubs

$\begin{array}{ll}\text { Natural } & \text { Trees } \\ & \end{array}$

Natural Grasses and trees

Natural Crops

Natural Grasses

Natural Trees

Natural Shrubs

Natural Grasses

Natural Grasses and shrubs

Natural Trees

Natural Trees

Natural Trees

Natural Trees

Natural Trees

Natural Trees

Natural Trees

Natural Trees

Natural Trees

Labeling Shrubs

Labeling Shrubs and trees

Natural Trees

Labeling Grasses and trees

Natural Trees

Natural Crops

Natural Shrubs and trees

Texture and classification

Classification

Texture

Texture

None

Clay content

Classification

None

None

None

Classification

Classification

Texture

Classification

None

Classification and formation

None

Classification

Texture

Structure
Texture

None

Texture and classification

Texture and bulk density

Classification

Classification

Texture

Classification

Physical properties

Classification

None

Particle size distribution

and physical properties

Texture

Natural Crops

Natural Trees

None

Texture

Texture

Texture

Texture

Natural Grasses

Natural Crops

Natural Grasses

Natural Shrubs

Texture

Natural Trees

Labeling Trees

Natural Crops a

Classification

Natural Crops

None

Texture

None irect inference (Brunel et al., 1995)

(Phillips and Gregg, 2003)

IsoSource (Phillips and Gregg, 2003)

IsoSource (Phillips and Gregg, 2003)

MixSir (Moore and Semmens, 2008)

Romero-Saltos et al. (2005)

Direct inference (Brunel et al., 1995) IsoSource (Phillips and Gregg, 2003) IsoSource (Phillips and Gregg, 2003) IsoSource (Phillips and Gregg, 2003) IsoSource (Phillips and Gregg, 2003) Romero-Saltos et al. (2005)

Biophysical model of Campbell (1991) None

Direct inference (Brunel et al., 1995) Direct inference (Brunel et al., 1995)

None

None

IsoSource (Phillips and Gregg, 2003) SIAR (Parnell et al., 2010)

IsoSource (Phillips and Gregg, 2003) IsoSource (Phillips and Gregg, 2003) IsoSource (Phillips and Gregg, 2003) IsoSource (Phillips and Gregg, 2003 IsoSource (Phillips and Gregg, 2003) IsoSource (Phillips and Gregg, 2003) SIAR (Parnell et al., 2010)

SIAR (Parnell et al., 2010)

SIAR (Parnell et al., 2010)

MixSir (Moore and Semmens, 2008)

MixSir (Moore and Semmens, 2008)

Proportional ${ }^{2} \mathrm{H}$ uptake

None

None

Thorburn (1993) - 2D mixing model IsoSource (Phillips and Gregg, 2003)

IsoSource (Phillips and Gregg, 2003)

IsoSource (Phillips and Gregg, 2003) IsoSource (Phillips and Gregg, 2003) IsoSource (Phillips and Gregg, 2003) IsoSource (Phillips and Gregg, 2003) IsoSource (Phillips and Gregg, 2003) IsoSource (Phillips and Greg, 2003) IsoSource (Phillips and Greg, 2003) IsoSource (Phillips and Gregg, 2003) SIAR (Parnell et al., 2010) SIAR (Parnell et al., 2010) SIAR (Parnell et al., 2010) SIAR (Parnell et al., 2010) MixSIAR (Moore and Semmens, 2008)

Proportional ${ }^{2} \mathrm{H}$ uptake

Table 1. Litterature overview obtained by entering the search terms (("root engine (webofknowledge.com). Date of consultation was January $18^{\text {th }}, 2017$. 
Alstad, K. P., Welker, J. M., Williams, S. A., and Trlica, M. J.: Carbon and water relations of Salix monticola in response to winter browsing and changes in surface water hydrology: an isotopic study using delta C-13 and delta O-18, Oecologia, 120, 375-385, doi: 10.1007/s004420050870, 1999.

Andrade, J. L., Meinzer, F. C., Goldstein, G., and Schnitzer, S. A.: Water uptake and transport in lianas and cooccurring trees of a seasonally dry tropical forest, Trees-Struct Funct, 19, 282-289, doi: 10.1007/s00468004-0388-x, 2005.

Angert, A., Barkan, E., Barnett, B., Brugnoli, E., Davidson, E. A., Fessenden, J., Maneepong, S., Panapitukkul, N., Randerson, J. T., Savage, K., Yakir, D., and Luz, B.: Contribution of soil respiration in tropical, temperate, and boreal forests to the O-18 enrichment of atmospheric O-2, Global Biogeochem Cy, 17, doi: 10.1029/2003gb002056, 2003.

Araki, H. and Iijima, M.: Stable isotope analysis of water extraction from subsoil in upland rice (Oryza sativa L.) as affected by drought and soil compaction, Plant Soil, 270, 147-157, doi: 10.1007/s11104-004-1304-2, 2005.

Armas, C., Padilla, F. M., Pugnaire, F. I., and Jackson, R. B.: Hydraulic lift and tolerance to salinity of semiarid species: consequences for species interactions, Oecologia, 162, 11-21, doi: 10.1007/s00442-009-1447-1, 2010.

Asbjornsen, H., Mora, G., and Helmers, M. J.: Variation in water uptake dynamics among contrasting agricultural and native plant communities in the Midwestern US, Agr Ecosyst Environ, 121, 343-356, doi: 10.1016/j.agee.2006.11.009, 2007.

Asbjornsen, H., Shepherd, G., Helmers, M., and Mora, G.: Seasonal patterns in depth of water uptake under contrasting annual and perennial systems in the Corn Belt Region of the Midwestern US, Plant Soil, 308, 6992, doi: 10.1007/s11104-008-9607-3, 2008.

Bachmann, D., Gockele, A., Ravenek, J. M., Roscher, C., Strecker, T., Weigelt, A., and Buchmann, N.: No evidence of complementary water use along a plant species richness gradient in temperate experimental grasslands, Plos One, 10, doi: 10.1371/journal.pone.0116367, 2015.

Barbeta, A., Mejia-Chang, M., Ogaya, R., Voltas, J., Dawson, T. E., and Penuelas, J.: The combined effects of a long-term experimental drought and an extreme drought on the use of plant-water sources in a Mediterranean forest, Global Change Biol., 21, 1213-1225, doi: 10.1111/gcb.12785, 2015.

Berry, Z. C., Hughes, N. M., and Smith, W. K.: Cloud immersion: an important water source for spruce and fir saplings in the southern Appalachian Mountains, Oecologia, 174, 319-326, doi: 10.1007/s00442-013-2770$0,2014$.

Bertrand, G., Masini, J., Goldscheider, N., Meeks, J., Lavastre, V., Celle-Jeanton, H., Gobat, J. M., and Hunkeler, D.: Determination of spatiotemporal variability of tree water uptake using stable isotopes ( $\mathrm{d} 18 \mathrm{O}, \mathrm{d} 2 \mathrm{H})$ in an alluvial system supplied by a high- altitude watershed, Pfyn forest, Switzerland, Ecohydrology, 7, 319333, doi: 10.1002/eco.1347, 2012.

Beyer, M., Koeniger, P., Gaj, M., Hamutoko, J. T., Wanke, H., and Himmelsbach, T.: A deuterium-based labeling technique for the investigation of rooting depths, water uptake dynamics and unsaturated zone water transport in semiarid environments, J. Hydrol., 533, 627-643, doi: 10.1016/j.jhydrol.2015.12.037, 2016.

Bijoor, N. S., McCarthy, H. R., Zhang, D. C., and Pataki, D. E.: Water sources of urban trees in the Los Angeles metropolitan area, Urban Ecosyst, 15, 195-214, doi: 10.1007/s11252-011-0196-1, 2012.

Bleby, T. M., Aucote, M., KennettSmith, A. K., Walker, G. R., and Schachtman, D. P.: Seasonal water use characteristics of tall wheatgrass [Agropyron elongatum (Host) Beauv.] in a saline environment, Plant Cell Environ, 20, 1361-1371, doi: 10.1046/j.1365-3040.1997.d01-29.x, 1997.

Boujamlaoui, Z., Bariac, T., Biron, P., Canale, L., and Richard, P.: Profondeur d'extraction racinaire et signature isotopique de l'eau prélevée par les racines des couverts végétaux, C. R. Geoscience, 337, 589-598, doi: 10.1016/j.crte.2005.02.003, 2005.

Brunel, J. P., Walker, G. R., Dighton, J. C., and Monteny, B.: Use of stable isotopes of water to determine the origin of water used by the vegetation and to partition evapotranspiration. A case study from HAPEX-Sahel, J. Hydrol., 189, 466-481, doi, 1997.

Brunel, J. P., Walker, G. R., and Kennettsmith, A. K.: Field validation of isotopic procedures for determining sources of water used by plants in a semiarid environment, J. Hydrol., 167, 351-368, doi: 10.1016/00221694(94)02575-V, 1995.

Busch, D. E., Ingraham, N. L., and Smith, S. D.: Water-Uptake in Woody Riparian Phreatophytes of the Southwestern United-States - a Stable Isotope Study, Ecol. Appl., 2, 450-459, doi: 10.2307/1941880, 1992.

Chen, Y. P., Chen, Y. N., Xu, C. C., and Li, W. H.: The effects of groundwater depth on water uptake of Populus euphratica and Tamarix ramosissima in the hyperarid region of Northwestern China, Environ Sci Pollut R, 23, 17404-17412, doi: 10.1007/s11356-016-6914-8, 2016.

Chimner, R. A. and Cooper, D. J.: Using stable oxygen isotopes to quantify the water source used for transpiration by native shrubs in the San Luis Valley, Colorado USA, Plant Soil, 260, 225-236, doi: 10.1023/B:Plso.0000030190.70085.E9, 2004. 
Comas, C., del Castillo, J., Voltas, J., and Ferrio, J. P.: Point processes statistics of stable isotopes: analysing water uptake patterns in a mixed stand of Aleppo pine and Holm oak, Forest Syst, 24, doi: 10.5424/fs/201524105846, 2015.

Costelloe, J. F., Payne, E., Woodrow, I. E., Irvine, E. C., Western, A. W., and Leaney, F. W.: Water sources accessed by arid zone riparian trees in highly saline environments, Australia, Oecologia, 156, 43-52, doi: 10.1007/s00442-008-0975-4, 2008.

Cramer, V. A., Thorburn, P. J., and Fraser, G. W.: Transpiration and groundwater uptake from farm forest plots of Casuarina glauca and Eucalyptus camaldulensis in saline areas of southeast Queensland, Australia, Agric. Water Manage., 39, 187-204, doi: 10.1016/S0378-3774(98)00078-X, 1999.

Dai, Y., Zheng, X. J., Tang, L. S., and Li, Y.: Stable oxygen isotopes reveal distinct water use patterns of two Haloxylon species in the Gurbantonggut Desert, Plant Soil, 389, 73-87, doi: 10.1007/s11104-014-2342-z, 2015.

Dawson, T. E. and Ehleringer, J. R.: Isotopic enrichment of water in the woody tissues of plants - Implications for plant water source, water-uptake, and other studies which use the stable isotopic composition of cellulose, Geochim. Cosmochim. Acta, 57, 3487-3492, doi: 10.1016/0016-7037(93)90554-A, 1993.

Dawson, T. E. and Ehleringer, J. R.: Streamside trees that do not use stream water, Nature, 350, 335-337, doi: 10.1038/350335a0, 1991

Dawson, T. E. and Pate, J. S.: Seasonal water uptake and movement in root systems of Australian phraeatophytic plants of dimorphic root morphology: A stable isotope investigation, Oecologia, 107, 13-20, doi: 10.1007/Bf00582230, 1996.

del Castillo, J., Comas, C., Voltas, J., and Ferrio, J. P.: Dynamics of competition over water in a mixed oak-pine Mediterranean forest: Spatio-temporal and physiological components, For. Ecol. Manage., 382, 214-224, doi: 10.1016/j.foreco.2016.10.025, 2016.

Deng, Y., Kuo, Y. M., Jiang, Z. C., Qin, X. M., and Jin, Z. J.: Using stable isotopes to quantify water uptake by Cyclobalanopsis glauca in typical clusters of karst peaks in China, Environ Earth Sci, 74, 1039-1046, doi: 10.1007/s12665-014-3780-x, 2015.

Dodd, M. B., Lauenroth, W. K., and Welker, J. M.: Differential water resource use by herbaceous and woody plant life-forms in a shortgrass steppe community, Oecologia, 117, 504-512, doi: 10.1007/s004420050686, 1998.

Drake, P. L., Froend, R. H., and Franks, P. J.: Linking hydraulic conductivity and photosynthesis to water-source partitioning in trees versus seedlings, Tree Physiol, 31, 763-773, doi: 10.1093/treephys/tpr068, 2011.

Eggemeyer, K. D., Awada, T., Harvey, F. E., Wedin, D. A., Zhou, X., and Zanner, C. W.: Seasonal changes in depth of water uptake for encroaching trees Juniperus virginiana and Pinus ponderosa and two dominant C(4) grasses in a semiarid grassland, Tree Physiol, 29, 157-169, doi: 10.1093/treephys/tpn019, 2009.

Ehleringer, J. R., Phillips, S. L., Schuster, W. S. F., and Sandquist, D. R.: Differential Utilization of Summer Rains by Desert Plants, Oecologia, 88, 430-434, doi: 10.1007/Bf00317589, 1991.

Ellsworth, P. Z. and Sternberg, L. S. L.: Seasonal water use by deciduous and evergreen woody species in a scrub community is based on water availability and root distribution, Ecohydrology, 8, 538-551, doi: 10.1002/eco.1523, 2015.

Emerman, S. H. and Dawson, T. E.: Experiments using split-root chambers on water uptake from soil macropores by sunflowers, Plant Soil, 189, 57-63, doi: 10.1023/A:1004250608543, 1997.

Esquivias, M. P., Zunzunegui, M., Barradas, M. C. D., and Alvarez-Cansino, L.: The role of water use and uptake on two Mediterranean shrubs' interaction in a brackish coastal dune ecosystem, Ecohydrology, 7, 783-793, doi: 10.1002/eco.1401, 2014.

Estrada-Medina, H., Santiago, L. S., Graham, R. C., Allen, M. F., and Jimenez-Osornio, J. J.: Source water, phenology and growth of two tropical dry forest tree species growing on shallow karst soils, Trees-Struct Funct, 27, 1297-1307, doi: 10.1007/s00468-013-0878-9, 2013

Evaristo, J., McDonnell, J. J., Scholl, M. A., Bruijnzeel, L. A., and Chun, K. P.: Insights into plant water uptake from xylem-water isotope measurements in two tropical catchments with contrasting moisture conditions, Hydrol. Process., 30, 3210-3227, doi: 10.1002/hyp.10841, 2016.

Ewe, S. M. L. and Sternberg, L. D. L.: Seasonal water-use by the invasive exotic, Schinus terebinthifolius, in native and disturbed communities, Oecologia, 133, 441-448, doi: 10.1007/s00442-002-1047-9, 2002.

Ewe, S. M. L., Sternberg, L. D. L., and Busch, D. E.: Water-use patterns of woody species in pineland and hammock communities of South Florida, For. Ecol. Manage., 118, 139-148, doi: 10.1016/S03781127(98)00493-9, 1999.

February, E. C., Bond, W., Taylor, R., and Newton, R.: Will water abstraction from the Table Mountain aquifer threaten endemic species? - A case study at Cape Point, Cape Town, S. Afr. J. Sci., 100, 253-255, doi, 2004.

February, E. C., Matimati, I., Hedderson, T. A., and Musil, C. F.: Root niche partitioning between shallow rooted succulents in a South African semi desert: implications for diversity, Plant Ecol., 214, 1181-1187, doi: 10.1007/s11258-013-0242-6, 2013.

Feikema, P. M., Morris, J. D., and Connell, L. D.: The water balance and water sources of a Eucalyptus plantation over shallow saline groundwater, Plant Soil, 332, 429-449, doi: 10.1007/s11104-010-0309-2, 2010. 
Fernandez, M. E., Gyenge, J., Licata, J., Schlichter, T., and Bond, B. J.: Belowground interactions for water between trees and grasses in a temperate semiarid agroforestry system, Agroforest Syst, 74, 185-197, doi: 10.1007/s10457-008-9119-4, 2008.

Flanagan, L. B., Ehleringer, J. R., and Marshall, J. D.: Differential Uptake of Summer Precipitation among Cooccurring Trees and Shrubs in a Pinyon-Juniper Woodland, Plant Cell Environ, 15, 831-836, doi: 10.1111/j.1365-3040.1992.tb02150.x, 1992.

Fritzsche, F., Abate, A., Fetene, M., Beck, E., Weise, S., and Guggenberger, G.: Soil-plant hydrology of indigenous and exotic trees in an Ethiopian montane forest, Tree Physiol, 26, 1043-1054, doi, 2006.

Gaines, K. P., Stanley, J. W., Meinzer, F. C., McCulloh, K. A., Woodruff, D. R., Chen, W., Adams, T. S., Lin, H., and Eissenstat, D. M.: Reliance on shallow soil water in a mixed-hardwood forest in central Pennsylvania, Tree Physiol, 36, 444-458, doi: 10.1093/treephys/tpv113, 2016.

Goebel, T. S., Lascano, R. J., Paxton, P. R., and Mahan, J. R.: Rainwater use by irrigated cotton measured with stable isotopes of water, Agric. Water Manage., 158, 17-25, doi: 10.1016/j.agwat.2015.04.005, 2015.

Greaver, T. L. and Sternberg, L. L. D.: Linking marine resources to ecotonal shifts of water uptake by terrestrial dune vegetation, Ecology, 87, 2389-2396, doi: 10.1890/0012-9658(2006)87, 2006.

Grieu, P., Lucero, D. W., Ardiani, R., and Ehleringer, J. R.: The mean depth of soil water uptake by two temperate grassland species over time subjected to mild soil water deficit and competitive association, Plant Soil, 230, 197-209, doi: 10.1023/A:1010363532118, 2001.

Grossiord, C., Gessler, A., Granier, A., Berger, S., Brechet, C., Hentschel, R., Hommel, R., Scherer-Lorenzen, M., and Bonal, D.: Impact of interspecific interactions on the soil water uptake depth in a young temperate mixed species plantation, J. Hydrol., 519, 3511-3519, doi: 10.1016/j.jhydrol.2014.11.011, 2014.

Gu, D. X., Zhang, Z. F., Mallik, A., Zhou, A. P., Mo, L., He, C. X., and Huang, Y. Q.: Seasonal water use strategy of Cyclobalanopsis glauca in a karst area of southern China, Environ Earth Sci, 74, 1007-1014, doi: 10.1007/s12665-014-3817-1, 2015.

Guo, F., Ma, J. J., Zheng, L. J., Sun, X. H., Guo, X. H., and Zhang, X. L.: Estimating distribution of water uptake with depth of winter wheat by hydrogen and oxygen stable isotopes under different irrigation depths, J Integr Agr, 15, 891-906, doi: 10.1016/S2095-3119(15)61258-8, 2016.

Hill, A. J., Dawson, T. E., Shelef, O., and Rachmilevitch, S.: The role of dew in Negev Desert plants, Oecologia, 178, 317-327, doi: 10.1007/s00442-015-3287-5, 2015.

Hoekstra, N. J., Finn, J. A., Hofer, D., and Luscher, A.: The effect of drought and interspecific interactions on depth of water uptake in deep- and shallow-rooting grassland species as determined by delta O-18 natural abundance, Biogeosciences, 11, 4493-4506, doi: 10.5194/bg-11-4493-2014, 2014.

Holdo, R. M. and Nippert, J. B.: Transpiration dynamics support resource partitioning in African savanna trees and grasses, Ecology, 96, 1466-1472, doi: 10.1890/14-1986.1, 2015.

Holland, K. L., Tyerman, S. D., Mensforth, L. J., and Walker, G. R.: Tree water sources over shallow, saline groundwater in the lower River Murray, south-eastern Australia: implications for groundwater recharge mechanisms, Aust. J. Bot., 54, 193-205, doi: 10.1071/Bt05019, 2006.

Hu, J., Hopping, K. A., Bump, J. K., Kang, S. C., and Klein, J. A.: Climate Change and Water Use Partitioning by Different Plant Functional Groups in a Grassland on the Tibetan Plateau, Plos One, 8, doi: 10.1371/journal.pone.0075503, 2013.

Huang, L. and Zhang, Z. S.: Stable Isotopic Analysis on Water Utilization of Two Xerophytic Shrubs in a Revegetated Desert Area: Tengger Desert, China, Water-Sui, 7, 1030-1045, doi: 10.3390/w7031030, 2015.

Iijima, M., Asai, T., Zegada-Lizarazu, W., Nakajima, Y., and Hamada, Y.: Productivity and water source of intercropped wheat and rice in a direct-sown sequential cropping system: The effects of no-tillage and drought, Plant Prod Sci, 8, 368-374, doi: 10.1626/pps.8.368, 2005.

Iijima, M., Morita, S., Zegada-Lizarazu, W., and Izumi, Y.: No-tillage enhanced the dependence on surface irrigation water in wheat and soybean, Plant Prod Sci, 10, 182-188, doi: 10.1626/pps.10.182, 2007.

Isaac, M. E., Anglaaere, L. C. N., Borden, K., and Adu-Bredu, S.: Intraspecific root plasticity in agroforestry systems across edaphic conditions, Agr Ecosyst Environ, 185, 16-23, doi: 10.1016/j.agee.2013.12.004, 2014.

Izumi, Y., Yoshida, T., and Iijima, M.: Effects of Subsoiling to the Non-tilled Field of Wheat-Soybean Rotation on the Root System Development, Water Uptake, and Yield, Plant Prod Sci, 12, 327-335, doi, 2009.

Jia, G. D., Yu, X. X., and Deng, W. P.: Seasonal water use patterns of semi-arid plants in China, Forest Chron, 89, 169-177, doi: 10.5558/tfc2013-034, 2013.

Jia, Z. Q., Zhu, Y. J., and Liu, L. Y.: Different Water Use Strategies of Juvenile and Adult Caragana intermedia Plantations in the Gonghe Basin, Tibet Plateau, Plos One, 7, doi: 10.1371/journal.pone.0045902, 2012.

Kerhoulas, L. P., Kolb, T. E., and Koch, G. W.: Tree size, stand density, and the source of water used across seasons by ponderosa pine in northern Arizona, For. Ecol. Manage., 289, 425-433, doi: 10.1016/j.foreco.2012.10.036, 2013.

Komor, S. C. and Magner, J. A.: Nitrate in groundwater and water sources used by riparian trees in an agricultural watershed: A chemical and isotopic investigation in southern Minnesota, Water Resour. Res., 32, 1039-1050, doi: 10.1029/95wr03815, 1996.

Kowaljow, E. and Fernandez, R. J.: Differential utilization of a shallow-water pulse by six shrub species in the Patagonian steppe, J. Arid Environ., 75, 211-214, doi: 10.1016/j.jaridenv.2010.10.004, 2011. 
Kulmatiski, A., Beard, K. H., and Stark, J. M.: Exotic plant communities shift water-use timing in a shrub-steppe ecosystem, Plant Soil, 288, 271-284, doi: 10.1007/s11104-006-9115-2, 2006.

Kulmatiski, A., Beard, K. H., Verweij, R. J. T., and February, E. C.: A depth-controlled tracer technique measures vertical, horizontal and temporal patterns of water use by trees and grasses in a subtropical savanna, New Phytol., 188, 199-209, doi: 10.1111/j.1469-8137.2010.03338.x, 2010.

Lambs, L., Muller, E., and Fromard, F.: Mangrove trees growing in a very saline condition but not using seawater, Rapid Commun. Mass Spectrom., 22, 2835-2843, doi: 10.1002/rcm.3676, 2008.

Le Roux, X. and Bariac, T.: Seasonal variations in soil, grass and shrub water status in a West African humid savanna, Oecologia, 113, 456-466, doi, 1998.

Leng, X., Cui, J., Zhang, S. T., Zhang, W. G., Liu, Y. H., Liu, S. R., and An, S. Q.: Differential water uptake among plant species in humid alpine meadows, Journal of Vegetation Science, 24, 138-147, doi: 10.1111/j.16541103.2012.01439.x, 2013.

Leroux, X., Bariac, T., and Mariotti, A.: Spatial partitioning of the soil-water resource between grass and shrub components in a west-African humid savanna, Oecologia, 104, 147-155, doi: 10.1007/BF00328579, 1995.

Li, S. G., Romero-Saltos, H., Tsujimura, M., Sugimoto, A., Sasaki, L., Davaa, G., and Oyunbaatar, D.: Plant water sources in the cold semiarid ecosystem of the upper Kherlen River catchment in Mongolia: A stable isotope approach, J. Hydrol., 333, 109-117, doi: 10.1016/j.jhydrol.2006.07.020, 2007.

Lin, G. H. and Sternberg, L. D. L.: Utilization of Surface-Water by Red Mangrove (Rhizophora-Mangle L) - an Isotopic Study, Bull. Mar. Sci., 54, 94-102, doi, 1994.

Link, C. M., Thevathasan, N. V., Gordon, A. M., and Isaac, M. E.: Determining tree water acquisition zones with stable isotopes in a temperate tree-based intercropping system, Agroforest Syst, 89, 611-620, doi: 10.1007/s10457-015-9795-9, 2015.

Liu, W. J., Li, P. J., Duan, W. P., and Liu, W. Y.: Dry-season water utilization by trees growing on thin karst soils in a seasonal tropical rainforest of Xishuangbanna, Southwest China, Ecohydrology, 7, 927-935, doi: 10.1002/eco.1419, 2014.

Liu, W. J., Liu, W. Y., Li, P. J., Duan, W. P., and Li, H. M.: Dry season water uptake by two dominant canopy tree species in a tropical seasonal rainforest of Xishuangbanna, SW China, Agr. Forest Meteorol., 150, 380-388, doi: 10.1016/j.agrformet.2009.12.006, 2010.

Liu, Y. H., Xu, Z., Duffy, R., Chen, W. L., An, S. Q., Liu, S. R., and Liu, F. D.: Analyzing relationships among water uptake patterns, rootlet biomass distribution and soil water content profile in a subalpine shrubland using water isotopes, Eur J Soil Biol, 47, 380-386, doi: 10.1016/j.ejsobi.2011.07.012, 2011.

Ma, Y. and Song, X. F.: Using stable isotopes to determine seasonal variations in water uptake of summer maize under different fertilization treatments, Sci. Total Environ., 550, 471-483, doi: 10.1016/j.scitotenv.2016.01.148, 2016.

Martin-Gomez, P., Barbeta, A., Voltas, J., Penuelas, J., Dennis, K., Palacio, S., Dawson, T. E., and Ferrio, J. P.: Isotope-ratio infrared spectroscopy: a reliable tool for the investigation of plant-water sources?, New Phytol., 207, 914-927, doi: 10.1111/nph.13376, 2015.

McCole, A. A. and Stern, L. A.: Seasonal water use patterns of Juniperus ashei on the Edwards Plateau, Texas, based on stable isotopes in water, J. Hydrol., 342, 238-248, doi: 10.1016/j.jhydrol.2007.05.024, 2007.

Meinzer, F. C., Andrade, J. L., Goldstein, G., Holbrook, N. M., Cavelier, J., and Wright, S. J.: Partitioning of soil water among canopy trees in a seasonally dry tropical forest, Oecologia, 121, 293-301, doi: 10.1007/s004420050931, 1999.

Meissner, M., Kohler, M., Schwendenmann, L., and Holscher, D.: Partitioning of soil water among canopy trees during a soil desiccation period in a temperate mixed forest, Biogeosciences, 9, 3465-3474, doi: 10.5194/bg9-3465-2012, 2012.

Midwood, A. J., Boutton, T. W., Archer, S. R., and Watts, S. E.: Water use by woody plants on contrasting soils in a savanna parkland: assessment with $\delta^{2} \mathrm{H}$ and $\delta^{18} \mathrm{O}$ Plant Soil, 205, 13-24, doi: 10.1023/A:1004355423241, 1998.

Moreira, M. Z., Sternberg, L. D. L., and Nepstad, D. C.: Vertical patterns of soil water uptake by plants in a primary forest and an abandoned pasture in the eastern Amazon: an isotopic approach, Plant Soil, 222, 95-107, doi: 10.1023/A:1004773217189, 2000.

Moreno-Gutierrez, C., Dawson, T. E., Nicolas, E., and Querejeta, J. I.: Isotopes reveal contrasting water use strategies among coexisting plant species in a Mediterranean ecosystem, New Phytol., 196, 489-496, doi: 10.1111/j.1469-8137.2012.04276.x, 2012.

Muench, A. T., O'Keefe, K., and Nippert, J. B.: Comparative ecohydrology between Cornus drummondii and Solidago canadensis in upland tallgrass prairie, Plant Ecol., 217, 267-276, doi: 10.1007/s11258-016-0567-z, 2016.

Nie, Y. P., Chen, H. S., Wang, K. L., and Yang, J.: Water source utilization by woody plants growing on dolomite outcrops and nearby soils during dry seasons in karst region of Southwest China, J. Hydrol., 420, 264-274, doi: 10.1016/j.jhydrol.2011.12.011, 2012.

Nippert, J. B. and Knapp, A. K.: Linking water uptake with rooting patterns in grassland species, Oecologia, 153, 261-272, doi: 10.1007/s00442-007-0745-8, 2007. 
Ogle, K., Tucker, C., and Cable, J. M.: Beyond simple linear mixing models: process-based isotope partitioning of ecological processes, Ecol. Appl., 24, 181-195, doi: 10.1890/1051-0761-24.1.181, 2014.

Ogle, K., Wolpert, R. L., and Reynolds, J. F.: Reconstructing plant root area and water uptake profiles, Ecology, 85, 1967-1978, doi: 10.1890/03-0346, 2004.

Pate, J. S. and Dawson, T. E.: Assessing the performance of woody plants in uptake and utilisation of carbon, water and nutrients - Implications for designing agricultural mimic systems, Agroforest Syst, 45, 245-275, doi: 10.1023/A:1006210109339, 1999.

Phillips, S. L. and Ehleringer, J. R.: Limited Uptake of Summer Precipitation by Bigtooth Maple (AcerGrandidentatum Nutt) and Gambels Oak (Quercus-Gambelii Nutt), Trees-Struct Funct, 9, 214-219, doi, 1995.

Plamboeck, A. H., Grip, H., and Nygren, U.: A hydrological tracer study of water uptake depth in a Scots pine forest under two different water regimes, Oecologia, 119, 452-460, doi: 10.1007/s004420050807, 1999.

Prechsl, U. E., Burri, S., Gilgen, A. K., Kahmen, A., and Buchmann, N.: No shift to a deeper water uptake depth in response to summer drought of two lowland and sub-alpine $\mathrm{C}_{3}$-grasslands in Switzerland, Oecologia, 177, 97-111, doi: 10.1007/s00442-014-3092-6, 2015.

Priyadarshini, K. V. R., Prins, H. H. T., de Bie, S., Heitkonig, I. M. A., Woodborne, S., Gort, G., Kirkman, K., Ludwig, F., Dawson, T. E., and de Kroon, H.: Seasonality of hydraulic redistribution by trees to grasses and changes in their water-source use that change tree-grass interactions, Ecohydrology, 9, 218-228, doi: 10.1002/eco.1624, 2016.

Querejeta, J. I., Estrada-Medina, H., Allen, M. F., and Jimenez-Osornio, J. J.: Water source partitioning among trees growing on shallow karst soils in a seasonally dry tropical climate, Oecologia, 152, 26-36, doi: 10.1007/s00442-006-0629-3, 2007.

Retzlaff, W. A., Blaisdell, G. K., and Topa, M. A.: Seasonal charges in water source of four families of loblolly pine (Pinus taeda L.), Trees-Struct Funct, 15, 154-162, doi: 10.1007/s004680100087, 2001.

Rossatto, D. R., Silva, L. D. R., Villalobos-Vega, R., Sternberg, L. D. L., and Franco, A. C.: Depth of water uptake in woody plants relates to groundwater level and vegetation structure along a topographic gradient in a neotropical savanna, Environ. Exp. Bot., 77, 259-266, doi: 10.1016/j.envexpbot.2011.11.025, 2012.

Rossatto, D. R., Sternberg, L. D. L., and Franco, A. C.: The partitioning of water uptake between growth forms in a Neotropical savanna: do herbs exploit a third water source niche?, Plant Biol., 15, 84-92, doi: 10.1111/j.1438-8677.2012.00618.x, 2013.

Rothfuss, Y., Braud, I., Le Moine, N., Biron, P., Durand, J. L., Vauclin, M., and Bariac, T.: Factors controlling the isotopic partitioning between soil evaporation and plant transpiration: Assessment using a multi-objective calibration of SiSPAT-Isotope under controlled conditions, J. Hydrol., 442, 75-88, doi: 10.1016/j.jhydrol.2012.03.041, 2012.

Roupsard, O., Ferhi, A., Granier, A., Pallo, F., Depommier, D., Mallet, B., Joly, H. I., and Dreyer, E.: Reverse phenology and dry-season water uptake by Faidherbia albida (Del.) A. Chev. in an agroforestry parkland of Sudanese west Africa, Funct. Ecol., 13, 460-472, doi: 10.1046/j.1365-2435.1999.00345.x, 1999.

Rowland, D. L., Leffler, A. J., Sorensen, R. B., Dorner, J. W., and Lamb, M. C.: Testing the efficacy of deuterium application for tracing water uptake in peanuts, T Asabe, 51, 455-461, doi, 2008.

Saha, A. K., Sternberg, L. D. L. O., and Miralles-Wilhelm, F.: Linking water sources with foliar nutrient status in upland plant communities in the Everglades National Park, USA, Ecohydrology, 2, 42-54, doi: 10.1002/eco.38, 2009.

Saha, A. K., Sternberg, L. D. O., Ross, M. S., and Miralles-Wilhelm, F.: Water source utilization and foliar nutrient status differs between upland and flooded plant communities in wetland tree islands, Wetlands Ecol. Manage., 18, 343-355, doi: 10.1007/s11273-010-9175-1, 2010.

Sánchez-Perez, J. M., Lucot, E., Bariac, T., and Tremolieres, M.: Water uptake by trees in a riparian hardwood forest (Rhine floodplain, France), Hydrol. Process., 22, 366-375, doi: 10.1002/hyp.6604, 2008.

Santini, N. S., Reef, R., Lockington, D. A., and Lovelock, C. E.: The use of fresh and saline water sources by the mangrove Avicennia marina, Hydrobiologia, 745, 59-68, doi: 10.1007/s10750-014-2091-2, 2015.

Schwendenmann, L., Pendall, E., Sanchez-Bragado, R., Kunert, N., and Holscher, D.: Tree water uptake in a tropical plantation varying in tree diversity: interspecific differences, seasonal shifts and complementarity, Ecohydrology, 8, 1-12, doi: 10.1002/eco.1479, 2015.

Schwinning, S.: The water relations of two evergreen tree species in a karst savanna, Oecologia, 158, 373-383, doi: 10.1007/s00442-008-1147-2, 2008.

Schwinning, S., Davis, K., Richardson, L., and Ehleringer, J. R.: Deuterium enriched irrigation indicates different forms of rain use in shrub/grass species of the Colorado Plateau, Oecologia, 130, 345-355, doi: 10.1007/s00442-001-0817-0, 2002.

Sekiya, N. and Yano, K.: Do pigeon pea and sesbania supply groundwater to intercropped maize through hydraulic lift? Hydrogen stable isotope investigation of xylem waters, Field Crops Res., 86, 167-173, doi: 10.1016/j.fcr.2003.08.007, 2004.

Sekiya, N. and Yano, K.: Water acquisition from rainfall and groundwater by legume crops developing deep rooting systems determined with stable hydrogen isotope compositions of xylem waters, Field Crops Res., 78, 133139, doi: 10.1016/S0378-4290(02)00120-X, 2002. 
Singer, M. B., Stella, J. C., Dufour, S., Piegay, H., Wilson, R. J. S., and Johnstone, L.: Contrasting water-uptake and growth responses to drought in co-occurring riparian tree species, Ecohydrology, 6, 402-412, doi: 10.1002/eco.1283, 2013.

Snyder, K. A. and Williams, D. G.: Defoliation alters water uptake by deep and shallow roots of Prosopis velutina (Velvet Mesquite), Funct. Ecol., 17, 363-374, doi: 10.1046/j.1365-2435.2003.00739.x, 2003.

Snyder, K. A. and Williams, D. G.: Root allocation and water uptake patterns in riparian tree saplings: Responses to irrigation and defoliation, For. Ecol. Manage., 246, 222-231, doi: 10.1016/j.foreco.2007.04.032, 2007.

Song, L. N., Zhu, J. J., Li, M. C., and Zhang, J. X.: Water use patterns of Pinus sylvestris var. mongolica trees of different ages in a semiarid sandy lands of Northeast China, Environ. Exp. Bot., 129, 94-107, doi: 10.1016/j.envexpbot.2016.02.006, 2016.

Stahl, C., Herault, B., Rossi, V., Burban, B., Brechet, C., and Bonal, D.: Depth of soil water uptake by tropical rainforest trees during dry periods: does tree dimension matter?, Oecologia, 173, 1191-1201, doi: 10.1007/s00442-013-2724-6, 2013.

Sternberg, L. D. S. L., Moreira, M. Z., and Nepstad, D. C.: Uptake of water by lateral roots of small trees in an Amazonian Tropical Forest, Plant Soil, 238, 151-158, doi: 10.1023/A:1014214404699, 2002.

Stratton, L. C., Goldstein, G., and Meinzer, F. C.: Temporal and spatial partitioning of water resources among eight woody species in a Hawaiian dry forest, Oecologia, 124, 309-317, doi: 10.1007/s004420000384, 2000.

Stumpp, C., Stichler, W., Kandolf, M., and Simunek, J.: Effects of Land Cover and Fertilization Method on Water Flow and Solute Transport in Five Lysimeters: A Long-Term Study Using Stable Water Isotopes, Vadose Zone J., 11, doi: 10.2136/vzj2011.0075, 2012.

Sun, S. J., Meng, P., Zhang, J. S., and Wan, X. C.: Variation in soil water uptake and its effect on plant water status in Juglans regia L. during dry and wet seasons, Tree Physiol, 31, 1378-1389, doi: 10.1093/treephys/tpr116, 2011.

Thorburn, P. J. and Ehleringer, J. R.: Root water uptake of field-growing plants indicated by measurements of natural-abundance deuterium, Plant Soil, 177, 225-233, doi: 10.1007/Bf00010129, 1995.

Thorburn, P. J. and Walker, G. R.: Variations in Stream Water-Uptake by Eucalyptus-Camaldulensis with Differing Access to Stream Water, Oecologia, 100, 293-301, doi: 10.1007/Bf00316957, 1994.

Trogisch, S., Salmon, Y., He, J. S., Hector, A., and Scherer-Lorenzen, M.: Spatio-temporal water uptake patterns of tree saplings are not altered by interspecific interaction in the early stage of a subtropical forest, For. Ecol. Manage., 367, 52-61, doi: 10.1016/j.foreco.2016.02.018, 2016.

Volkmann, T. H. M., Haberer, K., Gessler, A., and Weiler, M.: High-resolution isotope measurements resolve rapid ecohydrological dynamics at the soil-plant interface, New Phytol., doi: 10.1111/nph.13868, 2016. doi: 10.1111/nph.13868, 2016.

Voltas, J., Lucabaugh, D., Chambel, M. R., and Ferrio, J. P.: Intraspecific variation in the use of water sources by the circum-Mediterranean conifer Pinus halepensis, New Phytol., 208, 1031-1041, doi: 10.1111/nph.13569, 2015.

Walker, C. D. and Richardson, S. B.: The use of stable isotopes of water in characterizing the source of water in vegetation, Chem Geol, 94, 145-158, doi: 10.1016/0168-9622(91)90007-J, 1991.

Wang, L., Mu, Y., Zhang, Q. F., and Zhang, X. C.: Groundwater use by plants in a semi-arid coal-mining area at the Mu Us Desert frontier, Environ Earth Sci, 69, 1015-1024, doi: 10.1007/s12665-012-2023-2, 2013.

Wang, P., Song, X. F., Han, D. M., Zhang, Y. H., and Liu, X.: A study of root water uptake of crops indicated by hydrogen and oxygen stable isotopes: A case in Shanxi Province, China, Agric. Water Manage., 97, 475-482, doi: 10.1016/j.agwat.2009.11.008, 2010.

Warren, C. P., Kulmatiski, A., and Beard, K. H.: A combined tracer/evapotranspiration model approach estimates plant water uptake in native and non-native shrub-steppe communities, J. Arid Environ., 121, 67-78, doi: 10.1016/j.jaridenv.2015.06.001, 2015.

Wei, Y. F., Fang, J., Liu, S., Zhao, X. Y., and Li, S. G.: Stable isotopic observation of water use sources of Pinus sylvestris var. mongolica in Horqin Sandy Land, China, Trees-Struct Funct, 27, 1249-1260, doi: 10.1007/s00468-013-0873-1, 2013.

Weltzin, J. F. and McPherson, G. R.: Spatial and temporal soil moisture resource partitioning by trees and grasses in a temperate savanna, Arizona, USA, Oecologia, 112, 156-164, doi: 10.1007/s004420050295, 1997.

White, J. W. C., Cook, E. R., Lawrence, J. R., and Broecker, W. S.: The D/H ratios of sap in trees - implications for water sources and tree-Ring D/H ratios, Geochim. Cosmochim. Acta, 49, 237-246, doi: 10.1016/00167037(85)90207-8, 1985.

Williams, D. G. and Ehleringer, J. R.: Intra- and interspecific variation for summer precipitation use in pinyonjuniper woodlands, Ecol. Monogr., 70, 517-537, doi: 10.1890/0012-9615(2000)070, 2000.

Wu, H. W., Li, X. Y., Li, J., Jiang, Z. Y., Chen, H. Y., Ma, Y. J., and Huang, Y. M.: Differential soil moisture pulse uptake by coexisting plants in an alpine Achnatherum splendens grassland community, Environ Earth Sci, 75, doi: 10.1007/s12665-016-5694-2, 2016a.

Wu, J. N., Liu, W. J., and Chen, C. F.: Can intercropping with the world's three major beverage plants help improve the water use of rubber trees?, J. Appl. Ecol., 53, 1787-1799, doi: 10.1111/1365-2664.12730, $2016 \mathrm{~b}$. 
Wu, Y. J., Du, T. S., Li, F. S., Li, S. E., Ding, R. S., and Tong, L.: Quantification of maize water uptake from different layers and root zones under alternate furrow irrigation using stable oxygen isotope, Agric. Water Manage., 168, 35-44, doi: 10.1016/j.agwat.2016.01.013, 2016c.

Xu, Q., Li, H., Chen, J. Q., Cheng, X. L., Liu, S. R., and An, S. Q.: Water use patterns of three species in subalpine forest, Southwest China: the deuterium isotope approach, Ecohydrology, 4, 236-244, doi: 10.1002/eco.179, 2011.

Yang, B., Wen, X. F., and Sun, X. M.: Seasonal variations in depth of water uptake for a subtropical coniferous plantation subjected to drought in an East Asian monsoon region, Agr. Forest Meteorol., 201, 218-228, doi: 10.1016/j.agrformet.2014.11.020, 2015.

Yang, H., Auerswald, K., Bai, Y. F., and Han, X. G.: Complementarity in water sources among dominant species in typical steppe ecosystems of Inner Mongolia, China, Plant Soil, 340, 303-313, doi: 10.1007/s11104-0100307-4, 2011.

Yin, L. H., Zhou, Y. X., Huang, J. T., Wenninger, J., Zhang, E., Hou, G. C., and Dong, J. Q.: Interaction between groundwater and trees in an arid site: Potential impacts of climate variation and groundwater abstraction on trees, J. Hydrol., 528, 435-448, doi: 10.1016/j.jhydrol.2015.06.063, 2015.

Zegada-Lizarazu, W. and Iijima, M.: Deep root water uptake ability and water use efficiency of pearl millet in comparison to other millet species, Plant Prod Sci, 8, 454-460, doi: 10.1626/pps.8.454, 2005.

Zegada-Lizarazu, W. and Iijima, M.: Hydrogen stable isotope analysis of water acquisition ability of deep roots and hydraulic lift in sixteen food crop species, Plant Prod Sci, 7, 427-434, doi: 10.1626/pps.7.427, 2004.

Zegada-Lizarazu, W., Izumi, Y., and Iijima, M.: Water competition of intercropped pearl millet with cowpea under drought and soil compaction stresses, Plant Prod Sci, 9, 123-132, doi: 10.1626/pps.9.123, 2006.

Zegada-Lizarazu, W., Kanyomeka, L., Izumi, Y., and Iijima, M.: Water acquisition from the seasonal wetland and root development of pearl millet intercropped with cowpea in a flooding ecosystem of northern Namibia, Plant Prod Sci, 10, 20-27, doi: 10.1626/pps.10.20, 2007.

Zencich, S. J., Froend, R. H., Turner, J. V., and Gailitis, V.: Influence of groundwater depth on the seasonal sources of water accessed by Banksia tree species on a shallow, sandy coastal aquifer, Oecologia, 131, 8-19, doi: 10.1007/s00442-001-0855-7, 2002.

Zhang, L., Dawes, W. R., Slavich, P. G., Meyer, W. S., Thorburn, P. J., Smith, D. J., and Walker, G. R.: Growth and ground water uptake responses of lucerne to changes in groundwater levels and salinity: lysimeter, isotope and modelling studies, Agric. Water Manage., 39, 265-282, doi: 10.1016/S0378-3774(98)00082-1, 1999.

Zhang, Y. C., Shen, Y. J., Sun, H. Y., and Gates, J. B.: Evapotranspiration and its partitioning in an irrigated winter wheat field: A combined isotopic and micrometeorologic approach, J. Hydrol., 408, 203-211, doi: 10.1016/j.jhydrol.2011.07.036, 2011.

Zhao, P., Tang, X. Y., Zhao, P., and Tang, J. L.: Dynamics of water uptake by maize on sloping farmland in a shallow Entisol in Southwest China, Catena, 147, 511-521, doi: 10.1016/j.catena.2016.08.001, 2016.

Zhu, L., Wang, Z. H., Mao, G. L., Zheng, S. X., and Xu, X.: Water uptake from different soil depths for halophytic shrubs grown in Northern area of Ningxia plain (China) in contrasted water regimes, J Plant Interact, 9, 2634, doi: 10.1080/17429145.2012.751139, 2014.

Zhu, L., Zhang, H. L., Gao, X., Qi, Y. S., and Xu, X.: Seasonal patterns in water uptake for Medicago sativa grown along an elevation gradient with shallow groundwater table in Yanchi county of Ningxia, Northwest China, $\mathbf{J}$ Arid Land, 8, 921-934, doi: 10.1007/s40333-016-0017-8, $2016 \mathrm{a}$.

Zhu, Y. J., Wang, G. J., and Li, R. Q.: Seasonal Dynamics of Water Use Strategy of Two Salix Shrubs in Alpine Sandy Land, Tibetan Plateau, Plos One, 11, doi: 10.1371/journal.pone.0156586, 2016b.

Zubrinich, T. M., Loveys, B., Gallasch, S., Seekamp, J. V., and Tyerman, S. D.: Tolerance of salinized floodplain conditions in a naturally occurring Eucalyptus hybrid related to lowered plant water potential, Tree Physiol, 20, 953-963, doi, 2000. 